\title{
Peningkatan Hasil Belajar Materi Satuan Waktu Melalui Penerapan Metode Make a Match
}

\author{
Nursanti Rajagukguk \\ SDN Kendangsari I/276 Surabaya \\ Jl. Kendangsari Blok S No.26, Kecamatan Tenggilis Mejoyo, Kota Surabaya \\ rajagukguk.1962@gmail.com
}

\begin{abstract}
This study aims to determine whether or not there is an increase in the learning outcomes of the Unit of Time material through the application of the make a match method to Class 3-A students of SD Negeri Kendangsari I/276 Surabaya and to find out how much the increase in the learning outcomes of the Unit of Time material through the application of the make a match method in Class 3-A students of SD Negeri Kendangsari I/276 Surabaya. The research was carried out with a two-cycle action implementation mechanism with two meetings in each cycle. The subjects of this study were students of class 3-A SD Negeri Kendangsari I/276 Surabaya, totaling 39 students. In the study, it was found that the percentage of student learning outcomes in the Time Unit material from before this learning model was applied which only had an average of 54.3 to 70.9 in the first cycle and 77.1 in the second cycle. Based on the results of data analysis and discussion, it can be concluded that there is an increase in the learning outcomes of the Time Unit material through the application of the make a match method to Class 3-A students of SD Negeri Kendangsari I/276 Surabaya. The increase in learning outcomes of the Time Unit material through the application of the make a match method in Class 3-A students of SD Negeri Kendangsari I/276 Surabaya is an average of $23 \%$.
\end{abstract}

Keywords: Learning Outcomes, Units of Time, Make a Match Method

\begin{abstract}
Abstrak
Penelitian ini bertujuan untuk mengetahui ada tidaknya peningkatan hasil belajar materi Satuan Waktu melalui penerapan metode make a match pada siswa Kelas 3-A SD Negeri Kendangsari I/276 Surabaya dan untuk mengetahui seberapa besar peningkatan hasil belajar materi Satuan Waktu melalui penerapan metode make a match pada siswa Kelas 3-A SD Negeri Kendangsari I/276 Surabaya. Penelitian dilaksanakan dengan mekanisme pelaksanaan tindakan dua siklus dengan dilakukan dua pertemuan pada tiap siklusnya. Subjek penelitian ini adalah siswa kelas 3-A SD Negeri Kendangsari I/276 Surabaya yang berjumlah 39 siswa. Dalam penelitian ditemukan fakta tanjakan persentase hasil belajar materi Satuan Waktu siswa dari sebelum diterapkan model pembelajaran ini yang hanya memiliki rata-rata 54,3 menjadi 70,9 pada siklus I dan 77,1 pada siklus II. Berdasarkan hasil analisis data dan pembahasan dapat disimpulkan bahwa ada peningkatan hasil belajar materi Satuan Waktu melalui penerapan metode make a match pada siswa Kelas 3-A SD Negeri Kendangsari I/276 Surabaya. Peningkatan hasil belajar materi Satuan Waktu melalui penerapan metode make a match pada siswa Kelas 3-A SD Negeri Kendangsari I/276 Surabaya rata-rata sebesar 23\%.
\end{abstract}

Kata kunci: Hasil Belajar, Satuan Waktu, Metode Make a Match

Copyright (c) 2021 Nursanti Rajagukguk

Corresponding author: Nursanti Rajagukguk

Email Address: rajagukguk.1962@gmail.com (Jl. Kendangsari Blok S No.26, Kec Tenggilis Mejoyo, Surabaya) Received 09 September 2021, Accepted 06 October 2021, Published 10 November 2021

\section{PENDAHULUAN}

Beberapa hal yang menjadi kendala bagi pendidikan di Indonesia terutama pendidikan matematika, diantaranya adalah adanya kurikulum yang dikembangkan dengan hanya berdasar teori atau mencontoh atau mengadop dari kurikulum negara lain tanpa dikembangkan dari kasanah negeri sendiri, terlalu ingin cepat melihat hasil sehingga proses dinomorduakan, melupakan bahwa pendidikan adalah investasi masa depan yang hasilnya tidak dapat langsung dirasakan. Berikutnya adalah paradigma pembelajaran masih mengutamakan pandangan behaviorisitik, sehingga pemahaman dari 
pengetahuan yang diperoleh siswa jadi berkurang.

Menyimak pendidikan di Indonesia khususnya matematika di sekolah, baik di tingkat dasar sampai dengan tingkat lanjutan, belum pernah memberikan hal yang menggembirakan, baik untuk skala nasional maupun internasional. Indonesia masih jauh tertinggal oleh negara-negara lain meski di kancah Internasional secara individu siswa Indonesia ada yang berprestasi namun hal itu bukan merupakan potret dari pendidikan di Indonesia.

Tony Buzan, penemu dan pengembang metode mind map, menganalogikan bahwa belajar matematika ibaratnya membangun rumah-rumahan dari kartu. Setiap kartu harus berada di tempatnya sebelum kartu berikutnya ditambahkan. Kalau ada kartu yang keliru letaknya atau salah satu saja kartu yang goyah maka seluruh bangunan rumah-rumahan tersebut akan roboh. Satu hal lagi yang sangat menarik bahwa matematika dalam kurun “zaman keemasan” para kaum Muslimin sekitar abad kedelapan, adalah salah satu bidang ilmu yang paling digemari karena ada kaitannya dengan kebutuhan religi, misalnya untuk menghitung warisan dan kalender Islam, penentuan waktu shalat, menentukan waktu yang akurat dari gerakan bulan dan bintang, dan sebagainya. Sebagaimana diungkap oleh Mohaini Mohamed (2001) bahwa matematika menjadi kegemaran utama bagi kaum muslimin ketika itu karena bidang itu menggabungkan kesatuan dan karakter abstrak dari pemikiran Islam. Matematika tidak dianggap sebagai ajaran sekuler, tetapi lebih sebagai sarana untuk menyalurkan pemahaman pada bidang yang dapat dimengerti. Matematika, menurut kaum muslimin merupakan kunci menguak misteri tentang Tuhan.

Dari sekian banyak metode pembelajaran yang telah ada, salah satunya adalah model pembelajaran kooperatif berbantuan dengan metode make a match. Sebagaimana dikutip dalam Hasan Fauzi Maufur, metode make a match (mencari pasangan) pertama kali dikembangkan oleh Lorna Curran (1995) dalam mencari variasi mode berpasangan. Salah satu keunggulan teknik ini adalah siswa mencari pasangan sambil belajar mengenai suatu konsep atau topik dalam suasana yang menyenangkan. Teknik ini bisa digunakan dalam semua mata pelajaran dan untuk semua tingkatan usia. Metode ini cukup menyenangkan yang digunakan untuk mengulang materi yang telah diberikan sebelumnya. Namun demikian, materi baru pun tetap bisa diajarkan dengan metode ini. Oleh karena rendahnya hasil belajar materi Satuan Waktu yang dialami oleh siswa Kelas 3-A SDN Kendangsari I/276 Surabaya, maka penulis sebagai guru kelas mereka bertanggung jawab untuk menemukan solusi untuk meningkatkan hasil belajar materi Satuan Waktu.

Perspektif yang diambil adalah meningkatkan aktivitas siswa pada proses belajar mengajar. Hal ini berkaitan dengan pemilihan model pembelajaran, oleh karenanya inovasi penerapan model dan metode pembelajaran harus dilakukan melalui bentuk penerapan metode make a match. Tujuan penelitian ini adalah untuk mengetahui ada tidaknya peningkatan hasil belajar materi Satuan Waktu melalui penerapan metode make a match pada siswa Kelas 3-A SD Negeri Kendangsari I/276 Surabaya, dan untuk mengetahui seberapa besar peningkatan hasil belajar materi Satuan Waktu melalui penerapan metode make a match pada siswa Kelas 3-A SD Negeri Kendangsari I/276 Surabaya. 


\section{Hasil Belajar Matematika}

Hasil belajar adalah kemampuan-kemampuan yang dimiliki siswa setelah ia menerima pengalaman belajarnya. Hasil belajar menurut Dimyati adalah hasil proses belajar di mana pelaku aktif dalam belajar adalah siswa dan pelaku aktif dalam pembelajaran adalah guru. Hasil belajar adalah suatu penilaian akhir dari proses dan pengenalan yang telah dilakukan berulang-ulang. Menurut Nana Sudjana (2005:3) hasil belajar adalah perubahan tingkah laku siswa setelah melalui proses pembelajaran.

Proses pembelajaran sebagai suatu sistem yang terdiri dari komponen guru, siswa, bahan ajar dan lingkungan belajar yang berinteraksi satu sama lain dalam usaha unuk mencapai tujuan. Tujuan dari pembelajaran ini merupakan hasil belajar. Hasil belajar merupakan perubahan yang diperoleh pembelajar setelah mengalami aktivitas belajar (Chatarina Tri Ani dkk, 2004: 4). Sedangkan menurut Winkel dalam Sukestiyarno dan Budi Waluyo (2006: 6), hasil belajar merupakan bukti keberhasilan yang telah dicapai siswa atau siswa dimana setiap kegiatan belajar dapat menimbulkan suatu perubahan yang khas. Hasil belajar siswa dipengaruhi oleh dua faktor utama yaitu faktor dari dalam diri siswa (internal), dan faktor yang datang dari luar diri siswa (eksternal). Menurut Slameto (2003:54 - 72) faktor yang mempengaruhi hasil belajar adalah:

1. Faktor-faktor internal, meliputi jasmaniah (kesehatan, cacat tubuh), psikologis (intelegensi, perhatian, minat, bakat, kesiapan), dan kelelahan.

2. Faktor-faktor eksternal, meliputi keluarga, sekolah dan masyarakat lingkugan sekitar

Gagne, Robert M dan Leslie J. Briggs (1978: 49-55) menerangkan bahwa hasil belajar yang berkaitan dengan lima kategori tersebut adalah:(1) keterampilan intelektual adalah kecakapan yang berkenan dengan pengetahuan prosedural yang terdiri atas diskriminasi jamak, konsep konkret dan terdefinisi kaidah serta prinsip, (2) strategi kognitif adalah kemampuan untuk memecahkan masalahmasalah baru dengan jalan mengatur proses internal masing-masing individu dalam memperlihatkan, mengingat dan berfikir, (3) informasi verbal adalah kemampuan untuk mendiskripsiikan sesuatu dengan kata-kata dengan jalan mengatur informasi-informasi yang relevan, (4) keterampilan motorik adalah kemampuan untuk melaksanakan dan mengkoordinasikan gerakan-gerakan yang berhubungan dengan otot, (5) sikap merupakan kemampuan internal yang berperan dalam mengambil tindakan untuk menerima atau menolak berdasarkan penilaian terhadap obyek tersebut.

Penekanan pembelajaran matematika lebih diutamakan pada proses dengan tidak melupakan pencapaian tujuan. Proses ini lebih ditekankan pada proses belajar matematika seseorang. Tujuan yang paling utama dalam pembelajaran matematika adalah mengatur jalan pikiran dalam memecahkan masalah bukan hanya menguasai konsep dan perhitungan walaupun sebagian besar belajar matematika adalah belajar konsep struktur keterampilan menghitung dan menghubungkan konsep-konsep tersebut. Andi Hakim Nasution (1982: 12) mengemukakan bahwa dengan menguasai matematika orang akan belajar menambah kepandaiannya.

Sementara itu Nana Sudjana (1995: 22) mengemukakan bahwa hasil belajar matematika adalah kemamapuan-kemampuan yang dimiliki siswa setelah ia memperoleh pengalaman belajarnya. Gagne 
(1997: 47-48) mengelompokkan hasil belajar menjadi lima bagian dalam bentuk kapabilitas yakni keterampilan intelektual, strategi kognitif, informasi verbal, keterampilan motorik dan sikap.

Kata matematika berasal dari perkataan Latin mathematika yang mulanya diambil dari perkataan Yunani mathematik yang berarti mempelajari. Perkataan itu mempunyai asal katanya mathema yang berarti pengetahuan atau ilmu (knowledge, science). Kata mathematike berhubungan pula dengan kata lainnya yang hampir sama yaitu, mathein atau mathenein yang artinya belajar (berpikir). Jadi, berdasarkan asal katanya, maka perkataan matematika berarti ilmu pengetahuan yang didapat dengan berpikir (bernalar). Matematika lebih menekankan kegiatan dalam dunia rasio (penalaran), bukan menekankan hasil eksperimen atau hasil observasi matematika terbentuk karena pikiran-pikiran manusia, yang berhubungan dengan idea, proses dan penalaran (Ruseffendi, 1988:148).

Matematika terbentuk dari pengalaman manusia dalam dunianya secara empiris. Kemudian pengalaman itu diproses di dalam dunia rasio, diolah secara analisis dengan penalaran di dalam struktur kognitif sehingga sampai terbentuk konsep-konsep matematika supaya konsep-konsep matematika yang terbentuk itu mudah dipahami oleh orang lain dan dapat dimanipulasi secara tepat, maka digunakan bahasa matematika atau notasi matematika yang bernilai global. Konsep matematika didapat karena proses berpikir, karena itu logika adalah dasar terbentuknya matematika.

Tujuan mata pelajaran matematika yang tercantum dalam KTSP pada SD/MI adalah sebagai berikut:

1. Memahami konsep matematika, menjelaskan keterkaitan antar konsep dan mengaplikasikan konsep atau algoritma, secara luwes, akurat, efisien, dan tepat, dalam pemecahan masalah.

2. Menggunakan penalaran pada pola dan sifat, melakukan manipulasi matematika dalam membuat generalisasi, menyusun bukti, atau menjelaskan gagasan dan pernyataan matematika.

3. Memecahkan masalah yang meliputi kemampuan memahami masalah, merancang model matematika, menyelesaikan model dan menafsirkan solusi yang diperoleh.

4. Mengkomunikasikan gagasan dengan simbol, tabel, diagram, atau media lain untuk memperjelas keadaan atau masalah.

5. Memiliki sikap menghargai kegunaan matematika dalam kehidupan, yaitu memiliki rasa ingin tahu, perhatian, dan minat dalam mempelajari matematika, serta sikap ulet dan percaya diri dalam pemecahan masalah (Hamdani, 2008:10).

\section{Metode Make a Match}

Metode pembelajaran make and match adalah sistem pembelajaran yang mengutamakan penanaman kemampuan sosial terutama kemampuan bekerja sama, kemampuan berinteraksi disamping kemampuan berpikir cepat melalui permainan mencari pasangan dengan dibantu kartu (Wahab, 2007: 59). Metode make a match atau mencari pasangan merupakan salah satu alternatif yang dapat diterapkan kepada siswa. Penerapan metode ini dimulai dari teknik yaitu siswa disuruh mencari pasangan kartu yang merupakan jawaban/soal sebelum batas waktunya, siswa yang dapat mencocokkan kartunya diberi poin. Teknik metode pembelajaran make a match atau mencari pasangan dikembangkan oleh Lorna Curran (1994). Salah satu keunggulan tehnik ini adalah siswa mencari pasangan sambil belajar 
mengenai suatu konsep atau topik dalam suasana yang menyenangkan. Suyatno (2009: 72) mengungkapkan bahwa metode make a match adalah model pembelajaran dimana guru menyiapkan kartu yang berisi soal atau permasalahan dan menyiapkan kartu jawaban kemudian siswa mencari pasangan kartunya. Metode make a match merupakan bagian dari pembelajaran kooperatif. Model pembelajaran kooperatif didasarkan atas falsafah homo homini socius, falsafah ini menekankan bahwa manusia adalah mahluk sosial (Lie, 2003:27). Metode make a match melatih siswa untuk memiliki sikap sosial yang baik dan melatih kemampuan siswa dalam bekerja sama disamping melatih kecepatan berfikir siswa.

Menurut Rusman (2011: 223-233) Metode make a match (membuat pasangan) merupakan salah satu jenis dari metode dalam pembelajaran kooperatif. Metode ini dikembangkan oleh Lorna Curran (1994). Salah satu cara keunggulan teknik ini adalah siswa mencari pasangan sambil belajar mengenai suatu konsep atau topik, dalam suasana yang menyenangkan. Menurut Benny (2009: 1001), sebelum guru menggunakana metode make a match guru harus mempertimbangkan: (1) indikator yang ingin dicapai (2) kondisi kelas yang meliputi jumlah siswa dan efektifitas ruangan (3) alokasi waktu yang akan digunakan dan waktu persiapan. Pertimbangan diatas sangat diperlukan karena metode make a match tidak efektif apabila digunakan pada kelas yang jumlah siswanya diatas 60 dengan kondisi ruang kelas yang sempit. Sebab dalam pelaksanaan pembelajaran, make and match, kelas akan menjadi gaduh dan ramai. Hal ini wajar asalkan guru dapat mengendalikannya.

Teknik pembelajaran Make a Match dilakukan di dalam kelas dengan suasana yang menyenangkan karena dalam pembelajarannya siswa dituntut untuk berkompetisi mencari pasangan dari kartu yang sedang dibawanya dengan waktu yang cepat. Langkah - langkah model pembelajaran kooperatif tipe Make a Match (membuat pasangan) ini adalah sebagai berikut:

1. Guru menyiapkan beberapa konsep/topik yang cocok untuk sesi review (satu sisi kartu soal dan satu sisi berupa kartu jawaban beserta gambar).

2. Setiap siswa mendapat satu kartu dan memikirkan jawaban atau soal dari kartu yang dipegang.

3. Siswa mencari pasangan yang mempunyai kartu yang cocok dengan kartunya (kartu soal/kartu jawaban), siswa yang dapat mencocokkan kartunya sebelum batas waktu diberi point)

4. Setelah itu babak dicocokkan lagi agar tiap siswa mendapat kartu yang berbeda dari sebelumnya Kelebihan model pembelajaran tipe Make a Match antara lain: (1) dapat meningkatkan aktivitas belajar siswa, baik secara kognitif maupun fisik; (2) karena ada unsur permainan, metode ini menyengkan; (3) meningkatkan pemahaman siswa terhadap materi yang dipelajari dan dapat meningkatkan motivasi belajar siswa; (4) efektif sebagai sarana melatih keberanian siswa untuk tampil presentasi; dan (5) efektif melatih kedisiplinan siswa menghargai waktu untuk belajar.

Kelemahan media Make a Match antara lain: (1) jika strategi ini tidak dipersiapkan dengan baik, akan banyak waktu yang terbuang; (2) pada awal-awal penerapan metode, banyak siswa yang akan malu berpasangan dengan lawan jenisnya; (3) jika guru tidak mengarahkan siswa dengan baik, akan banyak siswa yang kurang memperhatikan pada saat presentasi pasangan; (4) guru harus hati-hati dan bijaksana 
saat member hukuman pada siswa yang tidak mendapat pasangan, karena mereka bisa malu; dan (5) menggunakan metode ini secara terus menerus akan menimbulkan kebosanan.

\section{METODE}

\section{Setting Penelitian}

Jenis penelitian yang dilakukan oleh peneliti yaitu penelitian tindakan kelas, yang lazim disebut PTK. Dengan demikian, penelitian ini sifatnya berbasis kelas, karena dilakukan dengan melibatkan komponen yang terdapat di dalam proses belajar mengajar di dalam kelas, materi pelajaran, dan metode pembelajaran. Tujuan dari penelitian ini tidak lain adalah untuk memperbaiki pembelajaran menulis dan meningkatkan kemampuan Menulis Cerita Sederhana siswa melalui metode latihan terbimbing dengan media teks lagu. Diharapkan dari penelitian ini hasil belajar dapat lebih maksimal.

Empat tahapan digunakan secara sistematis dalam proses penelitian ini, dan diterapkan dalam dua siklus, yaitu proses tindakan siklus I dan proses tindakan siklus II. Namun dalam hal ini, peneliti memerlukan kajian awal berupa renungan atau refleksi awal sebagai studi pendahuluan sebelum melakukan perencanaan penelitian. Hal ini dimaksudkan untuk mengetahui semua gejala atau informasi tentang situasi-situasi yang relevan dengan topik penelitian.

\section{Subyek Penelitian}

Penelitian ini dilaksanakan oleh penulis di SD Negeri Kendangsari I/276 dengan alamat Jl. Kendangsari Blok S No. 26 Kecamatan Tenggilis Mejoyo Kota Surabaya. Pelaksanaan penelitian dan perbaikan dijadwalkan oleh penulis dengan jadwal sebagai berikut:

Tabel 1. Waktu Pelaksanaan

\begin{tabular}{|l|l|c|c|c|}
\hline No & \multicolumn{1}{|c|}{ Jenis Kegiatan } & Januari & Pebruari & Maret \\
\hline 1 & Konsultasi dengan Kepala Sekolah. & M1 & & \\
\hline 2 & Mengajukan proposal penelitian. & M1 & & \\
\hline 3 & Mengajukan RPP & M2 & & \\
\hline 4 & Revisi RPP. & M3 & & \\
\hline 5 & Evaluasi kualitas RPP tahap akhir. & M4 & & \\
\hline 6 & Konsultasi dengan Observer. & M4 & M1-4 & \\
\hline 7 & Pelaksanaan siklus I. & & M1-4 & \\
\hline 8 & Pelaksanaan siklus II. & & M1-4 & \\
\hline 9 & Pelaksanaan siklus III. & & M1-4 & \\
\hline 10 & Menyusun laporan tindakan. & & & M1-3 \\
\hline
\end{tabular}

Kelas yang dijadikan obyek perbaikan dan penelitian adalah Kelas 3-A dengan jumlah siswa sebanyak 39 siswa.

\section{Teknik Pengumpulan Data}

Adapun teknik pengumpulan data yang penulis gunakan dalam penelitian ini adalah teknik nontes dan teknik tes. Teknik nontes alat penilaian yang dipergunakan untuk mendapatkan informasi 
tentang keadaan di tertes (testi, tercoba, inggris testee) tanpa dengan alat tes. Teknik nontes diperlukan untuk mendapatkan data yang tidak, atau paling tidak secara langsung, berkaitan dengan laku kognitif. Teknik ini diterapkan melalui kegiatan observasi dan pengumpulan dokumentasi.

Adapun teknik tes adalah teknik yang dilakukan untuk memperoleh data dengan menggunakan tes. Tes dilakukan sebanyak dua kali, yaitu pada siklus I dan pada siklus II. Materi tes dibuat penulis dengan memperhatikan buku panduan mata pelajaran Matematika. Tes digunakan untuk mengukur dasar dan pencapaian prestasi (Arikunto, 2002:196). Hasil tes siklus I dianalisis tersebut dapat diketahui kelemahan siswa, yang selanjutnya sebagai dasar untuk melengkapi siklus II. Hasil siklus II dianalisis sehingga dapat diketahui peningkatan hasil belajar.

\section{Validasi Data}

Uji instrumen ini menggunakan validitas isi dan permukaan. Validitas isi adalah derajat tes yang menggambarkan esensi, topik-topik, dan ruang lingkup tes yang dirancang untuk pengukuran, (Sevilla dalam Hardani 2006:39). Validitas isi dilakukan dengan menyesuaikan aspek keterampilan Menulis Cerita Sederhana berdasarkan landasan teori yang ada.

Validitas permukaan (paras) adalah tipe validitas yang berkaitan dengan tipe tes. Tipe validitas ini tidak didukung oleh bukti-bukti bahwa tes tersebut dapat mengukur sesuatu (Sevilla dalam Hardani 2006:39). Validitas permukaan dilakukan dengan cara dikonsultasikan dengan dosen pembimbing dan guru, sehingga dari pendapat mereka dapat disepakati bahwa instrumen yang akan digunakan dalam penelitian sudah valid.

\section{Teknik Analisa Data}

Dalam penelitian ini penulis menggunakan analisis data kualitatif dan analisis data kuantitatif. Teknik analisa data menggunakan teknik analisis kuantitatif dan kualitatif. Analisis data kualitatif pada penelitian ini diperoleh dari hasil observasi yang dilakukan oleh penulis yang memuat gambaran tingkat pengetahuansiswa terhadap suatu mata pelajaran, aktivitas dan antusiasme siswa saat mengikuti pelajaran setiap siklus.

Analisis data kuantitatif diperoleh dari hasil tes siswa yang bertujuan untuk mengetahui pengetahuansiswa tentang materi pelajaran dari setiap siklus, di mana siswa secara individu telah belajar tuntas atau berhasil apabila sekurang-kurangnya mendapat nilai 70. Standar penentuan ketuntasan belajar siswa menurut Sudjana (2006:109) sebagai berikut:

$$
\mathrm{P}=\sum_{\mathrm{N}} \mathrm{f} \times 100 \%
$$

Keterangan:

P : Persentase ketuntasan secara individu.

$\sum \mathrm{f} \quad$ : Jumlah nilai yang diperoleh siswa.

$\mathrm{N} \quad$ : $\quad$ Nilai maksimal.

Sedangkan untuk mencari persentase ketuntasan secara klasikal menggunakan rumus: 


$$
\mathrm{P}=\sum_{\mathrm{N}} \mathrm{n} \times 100 \%
$$

Keterangan:

P : $\quad$ Persentase ketuntasan belajar secara klasikal.

$\sum \mathrm{n} \quad$ : Jumlah siswa yang mendapat nilai $\geq 70$.

$\mathrm{N} \quad$ : Jumlah siswa seluruhnya.

Data pengamatan dianalisis dengan menghitung rata-rata pada setiap siklus yang dilaksanakan, selanjutnya nilai rata-rata tersebut diklasifikasikan dengan kriteria sebagai berikut:

$\begin{array}{ll}76-100 & \text { : Sangat baik } \\ 66-75 & \text { : Baik } \\ 46-65 & \text { : Cukup } \\ 0-45 & \text { : Kurang }\end{array}$

\section{Indikator Kinerja}

Indikator kinerja dalam penelitian ini sebagaimana terinci dalam tabel berikut:

Tabel 2. Indikator Aktivitas Guru

\begin{tabular}{|c|l|}
\hline No & \multicolumn{1}{|c|}{ Indikator aktivitas guru dalam metode make a match } \\
\hline 1 & Menyampaikan tujuan pembelajaran \\
\hline 2 & Mendeskripsikan materi yang dijadikan topik \\
\hline 3 & Membimbing siswa menjawab atau membuat pertanyaan pada kartu \\
\hline 4 & Mencocokkan kartu tepat waktu \\
\hline 5 & Mengevaluasi hasil jawaban \\
\hline
\end{tabular}

Tabel 3. Indikator Aktivitas Siswa

\begin{tabular}{|c|l|}
\hline No & \multicolumn{1}{|c|}{ Indikator aktivitas siswa dalam metode make a match } \\
\hline 1 & Mengetahui tujuan pembelajaran \\
\hline 2 & Memahami materi yang dijadikan topik \\
\hline 3 & Menjawab atau membuat pertanyaan pada kartu \\
\hline 4 & Mencocokkan kartu tepat waktu \\
\hline 5 & Mengevaluasi hasil jawaban \\
\hline
\end{tabular}

\section{Diskusi}

\section{Deskripsi Siklus I}

Pembelajaran pada siklus I dilaksanakan dalam waktu 2 × 3 × 25 menit dalam 2 kali pertemuan. Pertemuan siklus I direncanakan pada tanggal 6 dan 13 September 2021. Materi pembelajaran pada siklus ini adalah Mengukur Lama Kegiatan dengan Satuan Waktu. Penilaian dilakukan dengan menggunakan teknik tes tertulis dengan butir soal atau tugas sebagaimana termaktub dalam buku siswa. Kegiatan pembelajaran yang dilakukan ini sesuai dengan langkah-langkah metode make a match sebagai berikut:

1. Guru menyiapkan beberapa konsep/topik yang cocok untuk sesi review (satu sisi kartu soal dan 
satu sisi berupa kartu jawaban beserta gambar).

2. Setiap siswa mendapat satu kartu dan memikirkan jawaban atau soal dari kartu yang dipegang.

3. Siswa mencari pasangan yang mempunyai kartu yang cocok dengan kartunya (kartu soal/kartu jawaban), siswa yang dapat mencocokkan kartunya sebelum batas waktu diberi point)

4. Setelah itu babak dicocokkan lagi agar tiap siswa mendapat kartu yang berbeda dari sebelumnya

Penilaian observer tentang Aktivitas Guru pada Siklus I termasuk dalam kategori baik. Hal ini terlihat pada tahap pembelajaran kegiatan awal. Hal ini dipengaruhi oleh kemampuan guru dalam memotivasi siswa. Pada tahap kegiatan inti guru masih belum bisa melakukan improvisasi dan belum mengerti tentang langkah-langkah penyelesaian dalam pemecahan. Maka dari tinjauan ini, observer menyimpulkan bahwa pada tahap kegiatan Siklus I, tampaknya guru masih perlu bimbingan dalam hal mengimprovisasi langkah demi langkah dari metode yang digunakan.

Berdasarkan hasil observasi pada siklus I dapat disimpulkan bahwa pada siklus I rata-rata nilai hasil belajar materi Satuan Waktu siswa adalah 70,9 dan rata-rata kemampuan siswa dalam melaksanakan metode make a match adalah 13,8 atau 69\%. Hal ini bila diinterpretasikan ke dalam tabel interpretasi dengan rata-rata 70,9 maka termasuk ke dalam kategori baik. Adapun ketuntasan klasikal pada siklus I sebesar 59\% dengan kategori cukup.

Pada kegiatan refleksi, penulis lebih banyak mendasarkan upaya perbaikan pada hasil penilaian observer pada aktivitas penulis selama melaksanakan siklus I. Segala kekurangan pada pelaksanaan siklus tersebut akan direvisi pada siklus berikutnya dengan mempertimbangkan pendapat observer, serta segala aktivitas yang dinilai efektif akan dilanjutkan dan ditingkatkan.

Selain bagi siswa, metode make a match ini merupakan hal yang baru bagi penulis sehingga sempat agak bingung bagaimana cara menjelaskan aturan pelaksanaannya pada siswa. Di samping itu, penulis sempat meragukan apakah dengan model dan model pembelajaran ini hasil belajar materi Satuan Waktu siswa berubah

\section{Deskripsi Siklus II}

Pembelajaran pada siklus II dilaksanakan dalam waktu 2 × 3 x 25 menit dalam 2 kali pertemuan. Pertemuan siklus II direncanakan pada tanggal 20 dan 27 September 2021. Materi pembelajaran pada siklus ini adalah Mengukur Lama Kegiatan dengan Satuan Waktu. Penilaian dilakukan dengan menggunakan teknik tes tertulis dengan butir soal atau tugas sebagaimana termaktub dalam buku siswa. Kegiatan pembelajaran yang dilakukan ini sesuai dengan langkah-langkah metode make a match sebagai berikut:

1. Guru menyiapkan beberapa konsep/topik yang cocok untuk sesi review (satu sisi kartu soal dan satu sisi berupa kartu jawaban beserta gambar).

2. Setiap siswa mendapat satu kartu dan memikirkan jawaban atau soal dari kartu yang dipegang.

3. Siswa mencari pasangan yang mempunyai kartu yang cocok dengan kartunya (kartu soal/kartu jawaban), siswa yang dapat mencocokkan kartunya sebelum batas waktu diberi point)

4. Setelah itu babak dicocokkan lagi agar tiap siswa mendapat kartu yang berbeda dari sebelumnya 
Penilaian observer tentang Aktivitas Guru pada Siklus II termasuk dalam kategori sangat baik. Hal ini terlihat pada tahap pembelajaran kegiatan awal. Hal ini dipengaruhi oleh kepandaian guru dalam memotivasi siswa. Pada tahap kegiatan inti guru telah berhasil melakukan improvisasi pada langkahlangkah penyelesaian. Maka dari tinjauan ini, observer menyimpulkan bahwa pada tahap kegiatan Siklus II secara global berjalan dengan lancar.

Berdasarkan hasil observasi pada siklus II dapat disimpulkan bahwa pada siklus II rata-rata nilai hasil belajar materi Satuan Waktu siswa adalah 77,1 dan rata-rata kemampuan siswa dalam melaksanakan metode make a match adalah 15,1 atau $76 \%$. Hal ini bila diinterpretasikan ke dalam tabel interpretasi dengan rata-rata 77,1 maka termasuk ke dalam kategori baik. Adapun ketuntasan klasikal pada siklus II sebesar 85\% dengan kategori sangat baik.

Pada kegiatan refleksi, penulis lebih banyak mendasarkan upaya perbaikan pada hasil penilaian observer pada aktivitas penulis selama melaksanakan siklus II. Segala kekurangan pada pelaksanaan siklus tersebut akan direvisi pada siklus berikutnya dengan mempertimbangkan pendapat observer, serta segala aktivitas yang dinilai efektif akan dilanjutkan dan ditingkatkan. Selain bagi siswa, metode make a match ini merupakan hal yang menyenangkan bagi penulis sehingga pembelajaran menjadi hidup dan aktivitas siswa dalam belajar semakin meningkat. Metode make a match ini harus dilaksanakan secara berkesinambungan sebagai upaya pembiasaan bagi siswa.

Dengan demikian penerapan metode make a match memiliki efektifitas untuk meningkatkan nilai autentik dan hasil belajar materi Satuan Waktu siswa. Hal ini terlihat dari tanjakan persentase hasil belajar materi Satuan Waktu siswadari sebelum diterapkan model pembelajaran ini yang hanya memiliki rata-rata 54,3 menjadi 70,9 pada siklus I dan 77,1 pada siklus II.

Peningkatan kemampuan siswa dalam melaksanakan metode make a match sebesar $23 \%$ dari dua siklus ini jika ditelusuri lebih dalam adalah karena adanya faktor motivasi dari dalam diri siswa itu sendiri, apakah mereka mau menunjukkan seluruh aktivitas belajar yang menjadi indikator penelitian sepenuh hati mereka atau tidak. Model dan model pembelajaran yang diterapkan hanyalah faktor stimulus untuk memunculkan pembiasaan pada diri siswa.

Anggapan penulis ini tentu saja masih perlu dibuktikan dengan penelitian tindakan kelas lanjutan dari penelitian ini tiga atau empat bulan ke depan untuk menilai apakah pembiasaan dengan penggunaan model dan model pembelajaran tertentu memiliki signifikansi yang besar terhadap peningkatan hasil belajar materi Satuan Waktu siswa

\section{KESIMPULAN}

Berdasarkan paparan hasil penelitian dan pembahasan, dapat dirumuskan kesimpulan bahwa ada peningkatan hasil belajar materi Satuan Waktu melalui penerapan metode make a match pada siswa Kelas 3-A SD Negeri Kendangsari I/276 Surabaya. Peningkatan hasil belajar materi Satuan Waktu melalui penerapan metode make a match pada siswa Kelas 3-A SD Negeri Kendangsari I/276 Surabaya rata-rata sebesar 23\%. Upaya peningkatan hasil belajar materi Satuan Waktu melalui penerapan metode 
make a match dapat dijadikan acuan untuk mengadakan penelitian selanjutnya dengan sudut permasalahan berbeda atau solusi berbeda dengan permasalahan serupa. Selain itu juga dapat diimplementasikan sebagai bahan kajian bagi guru yang memiliki masalah dengan rendahnya prestasi belajarsiswa, khususnya prestasi belajar pada mata pelajaran matematika, agar tertangani secara akselaratif, efektif, dan efisien.

Berdasarkan simpulan hasil penelitian tersebut, peneliti memberikan saran agar guru khususnya guru kelas pada tingkat Sekolah Dasar agar dapat berimprovisasi dan berinovasi dalam melaksanakan tugasnya sebagai fasilitator belajar bagi siswa sehingga dengan demikian siswa termotivasi dan dapat mengikuti pembelajaran dengan antusias demi tercapainya tujuan pembelajaran yang telah ditetapkan sebelumnya. Selain itu, pihak sekolah dan masyarakat lingkugan sekitar hendaknya mendukung upaya penciptaan lingkungan pendidikan yang kondusif bagi siswa.

\section{UCAPAN TERIMA KASIH}

Terimakasih kami ucapkan kepada Kepala Sekolah dan Guru-guru di SDN Kendangsari I/276 Surabaya yang telah memberikan kesempatan kepada peneliti dalam melaksanakan penelitian. Tidak lupa rasa terimakasih juga kami sampaikan kepada siswa yang telah ikut berpartisipasi dalam melaksanakan penelitian ini.

\section{REFERENSI}

Arikunto, Suharsimi. 2004. Prosedur Penelitian. Yogyakarta: Rineka Cipta

Chatarina, Ani Tri. 2004. Psikologi Belajar. Semarang: Unnes Pres

Curran, L. 1994. Metode Pembelajaran Make a Match. Jakarta: Pustaka Pelajar.

Maufur, Fauzi, Hasan. 2009) Sejuta Jurus Mengajar Mengasyikkan. Semarang: Sindurr Press

Gagne, Robert M \& Briggs, Leslie J. 1978. Principles of Instructional Design. New York: Holt, Rinehart, and Winston

Hamdani. 2011. Strategi Belajar Mengajar. Bandung: Pustaka Setia.

Hardani, and Dkk. 2020. Buku Metode Penelitian Kualitatif \& Kuantitatif.

Yogyakarta: CV. Pustaka Ilmu.

Lie, A. 2003. Cooperative Learning. Mempraktikkan Cooperative Learning di Ruang-Ruang Kelas. Jakarta: PT. Grasindo

Lorna Curran. 1994. Metode Pembelajaran Make a Match. Jakarta: Pustaka Belajar.

Nasution, Andi Hakim, 1982. Landasan Matematika. Jakarta: Barata-Fajar

Pribadi, Benny A. 2009. Model Desain Sistem Pembelajaran. Jakarta: Dian Rakyat.

Ruseffendi, E.T. (1988). Pengajaran Matematika Modern dan Masa Kini Untuk Guru dan SPG, Bandung: Tarsito.

Rusman. 2011. Model-Model Pembelajaran Mengembangkan Profesionalisme Guru. Jakarta: PT. Rajagrafindo Persada 
Slameto. 2003. Belajar dan Faktor-Faktor yang Mempengaruhinya. Jakarta: Rineka Cipta Sudjana. 2005. Dasar-Dasar Proses Belajar Mengajar. Bandung: Sinar Baru Algensindo Sudjana, Nana. 2004. Penilaian Hasil Proses Belajar Mengajar. Bandung: Rosdakarya. Suyatno. 2009. Menjelajah Pembelajaran Inovatif. Bandung: Masmedia Buana Pustaka. Wahab. Abdul azis. 2007. Metode dan ModelModel Mengajar. Bandung: Alfabeta. 